\title{
PENTINGNYA MENGENAL RISIKO DAN PENCEGAHAN PENULARAN PENYAKIT ATAU CEDERA AKIBAT KECELAKAAN KERJA DALAM KEPERAWATAN
}

\section{Tati Oktiana Tamba}

Tatitamba26@gmail.com

\section{LATAR BELAKANG}

Perawat (nurse) berasal dari bahasa latin yaitu kata nutrix yang berarti merawat atau memelihara. Menurut Kusnanto (2003), perawat adalah seseorang (seorang profesional) yang mempunyai kemampuan, tanggung jawab dan kewenangan melaksanakan pelayanan/asuhan keperawatan pada berbagai jenjang pelayanan keperawatan. Perawat merupakan tenaga kesehatan yang memiliki peran penting dalam meningkatkan kesehatan pasien baik secara fisik maupun psikologis. Pekerjaan sebagai tenaga kesehatan terutama perawat menuntut untuk berinteraksi dalam merawat semua pasien dengan segala penyakit, baik penyakit menular dan tidak menular. Dinas Kesehatan (2017) menyatakan bahwa penyakit menular adalah penyakit yang disebabkan oleh mikroorganisme patogen seperti bakteri, virus, parasit atau jamur dan dapat ditularkan dari orang yang sakit ke orang yang sehat atau belum terkena penyakit menular melalui perantara maupun secara langsung.

Perilaku manusia merupakan unsur yang memegang peranan penting dalam mengakibatkan kecelakaan, sehingga cara yang efektif untuk mencegah terjadinya kecelakaan kerja adalah dengan menghindari terjadinya perilaku tidak aman. Tindakan tidak aman (unsafe action) adalah tindakan yang dapat membahayakan pekerja itu sendiri maupun orang lain yang dapat menyebabkan terjadinya kecelakaan yang dapat disebabkan oleh berbagai hal seperti tidak memakai APD, tidak mengikuti prosedur kerja, tidak mengikuti peraturan keselamatan kerja dan bekerja tidak hati-hati, dimana dari setiap 300 tindakan tidak aman, akan terjadi 1 (satu) kali kecelakaan yang mengakibatkan kehilangan hari kerja. Perilaku tidak aman perawat saat bekerja tanpa menggunakan alat pelindung diri sesuai standar dapat mengakibatkan kecelakaan kerja dan menimbulkan penyakit akibat kerja. Cedera adalah rasa sakit yang ditimbulkan akibat kecelakaan 
atau trauma, sehingga dapat menimbulkan cacat, luka, dan rusak pada otot atau sendi serta bagian lain dari tubuh (Eviani, 2012). Cedera atau luka adalah sesuatu kerusakan pada struktur atau fungsi tubuh yang dikarenakan suatu paksaan atau tekanan fisik maupun kimiawi. Luka juga dapat merujuk pada luka batin atau perasaan (Yuliana, 2013). Cedera akibat tusukan jarum pada perawat merupakan masalah yang signifikan dalam institusi pelayanan kesehatan dewasa ini. Ketika perawat tanpa sengaja menusuk dirinya sendiri dengan jarum suntik yang sebelumnya masuk ke dalam jaringan tubuh pasien, perawat beresiko terjangkit sekurang-kurangnya 20 patogen potensial.

Kesehatan dan Keselamatan Kerja (K3) adalah upaya untuk memberikan jaminan keselamatan dan meningkatkan derajat kesehatan pekerja dengan cara pencegahan kecelakaan dan Penyakit Akibat Kerja (PAK), pengendalian bahaya di tempat kerja, promosi kesehatan, pengobatan dan rehabilitasi. (Kepmenkes RI No.432/Menkes/SK/2007). Tujuan dari kesehatan dan keselamatan kerja adalah untuk memastikan bahwa dalam bekerja, tenaga kerja dalam keadaan baik baik saja. Perawat yang bekerja di rumah sakit memiliki resiko yang tinggi dalam penularan penyakit sehingga perawat harus mampu melindungi diri mereka sebelum kontak dengan pasien. Selain itu untuk menjaga kenyamanan pasien, perawat harus mengetahui penyakit-penyakit yang menular dan tidak menular sehingga tahu bagaimana tingkat resiko penularan penyakit tersebut kepada dirinya.

\section{METODE}

Metode yang digunakan dalam penulisan artikel ilmiah atau jurnal ini ialah dengan metode deskriptif. Dimana dilakukan dengan teknik pengumpulan data atau informasi dengan melakukan analisis, eksplorasi, kajian bebas (literatur review) yang relevan yang berfokus pada tema yaitu penyakit akibat kerja pada perawat. Adapun sumber yang digunakan dalam penulisan ini menggunakan sumber dari beberapa jurnal dengan memasukkan referensi kata kunci penyakit akibat kerja pada perawat yang telah ditentukan. Adapun referensi dari jurnal yang saya gunakan merupakan jurnal yang diterbitkan pada 8 tahun terakhir ( dengan tahun paling tua 2012). Dari deskriptif beberapa jurnal tersebut digunakan untuk mengetahui dan memahami pentingnya mengenal risiko pencegahan penularan penyakit atau cedera akibat kecelakaaan kerja dalam keperawatan. 


\section{HASIL}

Berdasarkan hasil analisis dan kajian bebas dari beberapa jurnal yang sesuai dengan topik yang di bahas.Maka dapat diperoleh bahwa pemicu penyakit atau cedera karena kerja yang dapat menyebabkan penyakit akibat kerja (PAK) pada perawat yang terjadi di Rumah Sakit (RS), umumnya berkaitan dengan:

1.Faktor biologis (kuman patogen yang berasal umumnya dari pasien)

2.Faktor kimia (pemaparan dalam dosis kecil namun terus menerus seperti antiseptik pada kulit, zat kimia/solvent yang menyebabkan kerusakan hati

3.Faktor ergonomi (cara duduk salah, cara mengangkat pasien salah)

4.Faktor fisik dalam dosis kecil yang terus menerus (panas pada kulit, tegangan tinggi, radiasi dll.)

5.Faktor psikologis (ketegangan di kamar penerimaan pasien, gawat darurat, karantina dll).

\section{Upaya pencegahan menurut standar K3 yaitu:}

1. Melakukan pencatatan kejadian Kecelakaan Akibat Kerja (KAK) sesuai dengan prosedur yang ditetapkan oleh petugas $\mathrm{K} 3$

2. Perlu dilakukan peningkatan terhadap penerapan pelayanan kesehatan kerja terutama pada pemeriksaan kesehatan khusus, pengobatan dan perawatan bagi penderita yang sakit, pemantauan lingkungan kerja serta ergonomi dan evaluasi pencatatan serta pelaporan kepada Direktur Rumah Sakit.

3. Perlu diadakan pemeriksaan kesehatan sebelum bekerja seperti pemeriksaan paru-paru, laboratorium maupun pemeriksaan secara fisik terhadap perawat IGD maupun tenaga medis yang lain.

4. Perlu diadakan kegiatansurvelans kerja seperti pemetaan tempat keja berdasarkan risiko bahayanya. 
5. Perlu diadakan penyesuaian terhadap peralatan kerja SDM Rumah Sakit seperti mengidentifikasi ergonomi terhadap peralatan kerja dan risiko peralatan kerjanya.

Seperti yang tercantum dalam Kepmenkes RI No. 1087 Tahun 2010 tentang standart kesehatan dan keselamatan kerja (K3) di Rumah Sakit bahwa penyesuaian terhadap peralatan kerja SDM dikatakan sudah diterapkan apabilah telah melakukan :

1. Identifikasi dan penilaian risiko ergonomi terhadap perlatan kerja dan SDM Rumah Sakit.

2. Membuat program pelaksanaan kegiatan, mengevaluasi dan mengendalikan risiko ergonomi.

Tujuan diterapkannya K3RS adalah terciptanya cara kerja, lingkungan kerja yang sehat, aman, nyaman, dan dalam rangka meningkatkan derajat kesehatan karyawan RS. Pengetahuan K3RS yang baik diharapkan mampu menekan angka kecelakaan kerja karena individu tersebut dapat menerapakan tindakan yang sesuai dengan pengetahuan $\mathrm{K} 3$ yang dimilikinya.

\section{PEMBAHASAN}

Perawat memainkan peran penting dalam sistem kesehatan suatu negara, terutama menyediakan layanan perawatan dan kesehatan bagi pasien. Perawat juga mempromosikan cara hidup sehat kepada masyarakat dengan menawarkan layanan pendidikan, menjalankan pemeriksaan kesehatan, bekerja dalam praktik, dan melakukan berbagai tugas tambahan terkait kesehatan. Penelitian tentang rumah sakit di Amerika pada tahun 2017 telah menunjukkan bahwa perawat memiliki tingkat insiden cedera dan penyakit yang lebih tinggi dibandingkan dengan profesi kesehatan lain (Dressner, 2017).

Kecelakaan kerja merupakan kejadian eksternal yang kebetulan, tiba-tiba, tidak terduga yang terjadi selama jam kerja dan atau dalam perjalanan ke dan dari tempat kerja. Konsep kecelakaan kerja didasarkan pada fakta bahwa harus ada hubungan sebab akibat antara peristiwa dengan cedera yang mengarah pada kerusakan fisik atau mental (Ghahramani \& Summala, 2015). Contoh kecelakaan kerja berdasarkan definisi tersebut, perawat terpeleset (slip), tersandung (trip), dan terjatuh (fall).

Pada umumnya kecerobohan perawat merupakan dampak dari beban kerja, perbandingan jumlah pasien yang tidak berbanding lurus dengan jumlah perawat, kekurangan sumber daya, peralatan 
bahkan infrastruktur menjadi salah satu penyebab utama kecelakaan. Kecelakaan akibat kerja dapat terjadi ketika perawat melupakan atau melewatkan tahapan sederhana namun berarti bagi kesehatan dan keselamatan pasien dan diri perawat (Bell, J. Collins, James. Dalsey, Elizabeth. Sublet, 2010). Tahapan tersebut seperti perawat tidak menggunakan prinsip one hand saat membuka dan menutup ampul maupun suntikan, tidak menutup, memutar atau melepas jarum bekas dengan prinsip satu tangan dan tidak membuang benda infeksius ke dalam wadah khusus infeksius yang telah disediakan.

Usaha pengendalian di lingkungan kerja rumah sakit sangat penting direncanakan dan diterapkan diantaranya mengkaji kesehatan kerja tenaga kesehatan, staf dan karyawan; standarisasi sanitasi lingkungan rumah sakit dan keamanan pasien dan pengunjung rs. Upaya-upaya yang bisa dikerjakan untuk mencegah kecelakaan kerja dan penyakit akibat kerja yaitu, pertama, substitusi pengenalan lingkungan kerja dengan cara mengkaji dan mengenali potensial bahaya lingkungan kerja, kemudian mengganti perlengkapan kerja yang tidak wajar gunakan (Ghahramani \& Summala, 2015). Kedua, pelajari lingkungan kerja dalam hal ini menilai karakter serta besarnya potensi-potensi bahaya yang mungkin muncul sehingga dengan mudah rs memprioritaskan dalam penanganan permasalahan yang lebih potensial. Ketiga, pengendalian lingkungan kerja dengan bertindak mengurangi bahkan juga menghilangkan pajanan pada masalah kesehatan tenaga medis di lingkungan kerja dengan menggunakan teknologi pengendalian (Kementerian Kesehatan Republik Indonesia, 2011).

Pengetahuan tentang pengontrolan cedera sangat perlu dan dibutuhkan dalam beberapa tahun terakhir ini yang ditujukan pada komponen hal-hal yang membahayakan kemanan yang berkontribusi pada cedera baik non fatal maupun fatal. Istilah kecelakaan tidak begitu luas akan digunakan dalam diskusi pencegahan cedera, karena kecelakaan diimpilikasikan pada kejadian yang terjadi karena kehendak Tuhan atau keberuntungan yang buruk, yang tidak dapat diduga, dan yang tidak dapat dicegah. Seperti halnya, kecelakaan, maka cedera memiliki sesuatu cara yang harus dicegah.

Prinsip pencegahan cedera termasuk pendidikan mengenai hal-hal yang membahayakan keamanan dan strategi pencegahan; pengontrolan lingkungan dan mesin-mesin (keamanan aktif atau pasif dikemudian hari yang mungkin mencegah cedera dari produk atau alat yang digunakan), dan penguatan pada pengaturan diantara peralatan, pengaman, tenaga kerja dan 
sebagainya. Keamanan aktif termasuk pemberian pengaturan pada tingkah laku seseorang yang dapat menguntungkannya. Keamanan pasif atau automatik termasuk pengaturan yang menggunakan mesin dan peralatan dan tidak membutuhkan tingkah laku seseorang yang spesifik untuk menjadi aktif. Kantung udara, pengaman tempat tidur adalah contoh dari keamanan pasif. Keamanan pasif adalah lebih menguntungkan dari pada keamanan aktif dalam pengerjaannya, karena tidak membutuhkan penjelasan atau pendidikan kepada klien atau individu tersebut. Salah satu risiko keamanan pasien selama berada dalam pelayanan di rumah sakit adalah kemungkinan pasien jatuh ( fall) (Setyarini, .2010).

World Health Organization (WHO) menyatakan, rumah sakit adalah institusi perawatan kesehatan yang memiliki staf medis profesional yang terorganisir, memiliki fasilitas rawat inap, dan memberikan layanan 24 jam. Menyediakan pelayanan komprehensif, penyembuhan penyakit (kuratif) dan pencegahan penyakit (preventif) kepada masyarakat (WHO, 2017). UndangUndang No. 44 Tahun 2009, mendefinisikan rumah sakit sebagai institusi pelayanan kesehatan yang memberikan pelayanan kesehatan perorangan secara menyeluruh dengan menyediakan pelayanan rawat inap, rawat jalan, dan gawat darurat. Rumah sakit sebagai salah satu bagian sistem pelayanan kesehatan yang memberikan pelayanan kepada masyarakat mencakup pelayanan medik, pelayanan penunjang medik, rehabilitasi medik dan pelayanan perawatan (Septiari, 2012).

Pada simposium internasional mengenai penyakit akibat hubungan pekerjaan yang diselenggarakan oleh ILO (International Labour Organization) di Linz, Austria, dihasilkan definisi menyangkut PAK sebagai berikut:

a. Penyakit Akibat Kerja - Occupational Disease adalah penyakit yang mempunyai penyebab yang spesifik atau asosiasi yang kuat dengan pekerjaan, yang pada umumnya terdiri dari satu agen penyebab yang sudah diakui.

b. Penyakit yang Berhubungan dengan Pekerjaan - Work Related Disease adalah penyakit yang mempunyai beberapa agen penyebab, dimana faktor pekerjaan memegang peranan bersama dengan faktor risiko lainnya dalam berkembangnya penyakit yang mempunyai etiologi kompleks. 
c. Penyakit yang Mengenai Populasi Kerja - Disease of Fecting Working Populations adalah penyakit yang terjadi pada populasi pekerja tanpa adanya agen penyebab ditempat kerja, namun dapat diperberat oleh kondisi pekerjaan yang buruk bagi kesehatan.

Tenaga kerja dalam UU No. 14 memiliki hak mendapatkan perlindungan atas kesehatan, keselamatan, kesusilaan, pemeliharaan moril kerja dan perlakuan yang sama dengan martabat manusia serta kepribadian agama. Dalam perihal ini memerlukan usaha perlindungan kesehatan serta keselamatan kerja buat petugas di lingkungan rumah sakit. Gangguan kesehatan pada pekerja bisa juga dipicu oleh aspek yang terkait dengan pekerjaan ataupun aspek yang tidak terkait dengan pekerjaan. Dengan begitu bisa dikatakan jika status kesehatan penduduk pekerja di pengaruhi bukan hanya oleh bahaya di lingkungan kerja tapi ikut oleh aspek kesehatan pekerja yang akan punya pengaruh pada perilaku pekerja yang tidak konsentrasi.

Risiko utama akibat kerja pada perawat adalah penyakit menular, cedera otot dan tulang, gangguan tidur.

\section{Penyakit menular}

Tenaga perawat kemungkinan melakukan kontak yang berhubungan dengan cairan darah berkuman, cairan tubuh, busa, cairan mulut, cairan urine, kotoran manusia, muntahan dan lainlain sehingga mendapat penularan.

\section{Media penularan :}

- Penularan melalui cairan darah

- Penularan melalui udara atau busa

- Penularan melalui kontak tubuh

- Penularan melalui mulut

- (Berkontak dengan cairan urine dan kotoran manusia)

Penyakit menular : Hepatitis B, hepatitis C, AIDS, Flu menular, TBC, SARS, Penyakit kulit biasa, radang infeksi kulitRadang infeksi perut, hepatitis A. 


\section{Sakit otot dan tulang}

Tindakan memindahkan pasien, membalikkan dan menepuk-nepuk punggung pasien, latihan penyembuhan, dikarenakan sering mengeluarkan tenaga berlebihan, gerakan yang tidak benar atau berulang-ulang, mudah menyebabkan cedera di bagian otot dan tulang, apabila tenaga perawat berusia agak tua, maka akan menambah resiko dan tingkat keseriusan cedera di otot dan tulang.

\section{Gangguan tidur}

Tenaga perawat perlu waktu sepanjang malam atau waktu yang tidak tentu untuk menjaga pasien, sehingga mudah mengalami kondisi tidur pendek, tidur kurang lelap, kesulitan tidur.

Beberapa faktor yang merupakan salah satu penyebab penyakit atau cedera pada perawat di tempat kerjanya sebagai berikut:

1. Akibat kelalaian perawat seperti tertusuk jarum atau tergores jarum, jika perawat terkena tusukan atau goresan jarum dari pasien yang menderita HIV dan Hepatitis B maka risiko perawat akan tertular penyakitnya.

2. Perawat berisiko terkena infeksi jika tidak cuci tangan atau menggunakan sarung tangan serta masker jika berada pada ruang paru.

3. Perawat sering kontak langsung dengan bahan kimia seperti obat - obatan kontak kerja tersebut yang pada umumnya dapat menyebabkan iritasi (amoniak, dioksan) dan hanya sedikit saja oleh karena alergi (keton). Bahan toksik (trichloroethane, tetrachloromethane) jika tertelan, terhirup atau terserap melalui kulit dapat menyebabkan penyakit akut atau kronik, bahkan kematian.

\section{Penyakit atau cedera akibat kerja di Tempat Kerja Kesehatan umumnya berkaitan dengan :}

\section{Faktor Biologis}

Lingkungan kerja pada Pelayanan Kesehatan favorable bagi berkembang biaknya strain kuman yang resisten, terutama kuman-kuman pyogenic, colli, bacilli dan staphylococci, yang 
bersumber dari pasien, benda-benda yang terkontaminasi dan udara. Virus yang menyebar melalui kontak dengan darah dan sekreta (misalnya HIV dan Hep. B) dapat menginfeksi pekerja hanya akibat kecelakaan kecil dipekerjaan, misalnya karena tergores atau tertusuk jarum yang terkontaminasi virus.

\section{Pencegahan :}

a. Seluruh pekerja harus mendapat pelatihan dasar tentang kebersihan, epidemilogi dan desinfeksi.

b. Sebelum bekerja dilakukan pemeriksaan kesehatan untuk memastikan dalam keadaan sehat badan, punya cukup kekebalan alami untuk bekerja dengan bahan infeksius, dan dilakukan imunisasi.

c. Menggunakan desinfektan yang sesuai dan cara penggunaan yang benar.

d. Sterilisasi dan desinfeksi terhadap tempat, peralatan, sisa bahan infeksius dan spesimen secara benar.

e. Pengelolaan limbah infeksius dengan benar.

f. Menggunakan kabinet keamanan biologis yang sesuai.

g. Kebersihan diri dari petugas.

\section{Faktor Kimia}

Petugas di tempat kerja kesehatan yang sering kali kontak dengan bahan kimia dan obatobatan seperti antibiotika, demikian pula dengan solvent yang banyak digunakan dalam komponen antiseptik, desinfektan dikenal sebagai zat yang paling karsinogen. Semua bahan cepat atau lambat ini dapat memberi dampak negatif terhadap kesehatan mereka. Gangguan kesehatan yang paling sering adalah dermatosis kontak akibat kerja yang pada umumnya disebabkan oleh iritasi (amoniak, dioksan) dan hanya sedikit saja oleh karena alergi (keton). Bahan toksik (trichloroethane, tetrachloromethane) jika tertelan, terhirup atau terserap melalui kulit dapat menyebabkan penyakit akut atau kronik, bahkan kematian. Bahan korosif (asam dan basa) akan mengakibatkan kerusakan jaringan yang irreversible pada daerah yang terpapar. 


\section{Pencegahan :}

a. "Material safety data sheet" (MSDS) dari seluruh bahan kimia yangada untuk diketahui oleh seluruh petugas untuk petugas atau tenaga kesehatan laboratorium.

b. Menggunakan karet isap (rubber bulb) atau alat vakum untuk mencegah tertelannya bahan kimia dan terhirupnya aerosol untuk petugas / tenaga kesehatan laboratorium.

c. Menggunakan alat pelindung diri (pelindung mata, sarung tangan, celemek, jas laboratorium) dengan benar.

d. Hindari penggunaan lensa kontak, karena dapat melekat antara mata dan lensa.

e. Menggunakan alat pelindung pernafasan dengan benar.

\section{Faktor Ergonomi}

Ergonomi sebagai ilmu, teknologi dan seni berupaya menyerasikan alat, cara, proses dan lingkungan kerja terhadap kemampuan, kebolehan dan batasan manusia untuk terwujudnya kondisi dan lingkungan kerja yang sehat, aman, nyaman dan tercapai efisiensi yang setinggitingginya. Sebagian besar pekerja di perkantoran atau Pelayanan Kesehatan pemerintah, bekerja dalam posisi yang kurang ergonomis, misalnya tenaga operator peralatan, Posisi kerja yang salah dan dipaksakan dapat menyebabkan mudah lelah sehingga kerja menjadi kurang efisien dan dalam jangka panjang dapat menyebakan gangguan fisik dan psikologis (stress) dengan keluhan yang paling sering adalah nyeri pinggang kerja (low back pain).

\section{Faktor Fisik}

Faktor fisik di laboratorium kesehatan yang dapat menimbulkan masalah kesehatan kerja meliputi:

a.Kebisingan, getaran akibat alat / media elektronik dapat menyebabkan stress dan ketulian.

b.Pencahayaan yang kurang di ruang kerja,laboratorium,ruang perawatan dan kantor administrasi dapat menyebabkan gangguan penglihatan dan kecelakaan kerja.

c.Suhu dan kelembaban yang tinggi di tempat kerja. 
d.Terimbas kecelakaan/kebakaran akibat lingkungan sekitar.Terkena radiasi

e.Khusus untuk radiasi, dengan berkembangnya teknologi pemeriksaan, penggunaannya meningkat sangat tajam dan jika tidak dikontrol dapat membahayakan petugas yang menangani.

\section{Pencegahan :}

a. Pengendalian cahaya di ruang kerja khususnya ruang laboratorium.

b. Pengaturan ventilasi dan penyediaan air minum yang cukup memadai.

c. Menurunkan getaran dengan bantalan anti vibrasi.

d. Pengaturan jadwal kerja yang sesuai.

e. Pelindung mata untuk sinar laser

f. Filter untuk mikroskop untuk pemeriksa demam berdarah

\section{Faktor Psikososial}

Beberapa contoh faktor psikososial di laboratorium kesehatan yang dapat menyebabkan stress :

a. Pelayanan kesehatan sering kali bersifat emergency dan menyangkut hidup mati seseorang. Untuk itu pekerja di tempat kerja kesehatan di tuntut untuk memberikan pelayanan yang tepat dan cepat disertai dengan kewibawaan dan keramahan-tamahan

b. Pekerjaan pada unit-unit tertentu yang sangat monoton.Hubungan kerja yang kurang serasi antara pimpinan dan bawahan atau sesama teman kerja.Beban mental karena menjadi panutan bagi mitra kerja di sektor formal ataupun informal.

Perilaku tidak aman perawat saat bekerja tanpa menggunakan alat pelindung diri sesuai standar dapat mengakibatkan kecelakaan kerja dan menimbulkan penyakit akibat kerja. Cedera akibat tusukan jarum pada perawat merupakan masalah yang signifikan dalam institusi pelayanan kesehatan dewasa ini. Ketika perawat tanpa sengaja menusuk dirinya sendiri dengan jarum suntik yang sebelumnya masuk ke dalam jaringan tubuh pasien, perawat beresiko terjangkit sekurangkurangnya 20 patogen potensial. Dua pathogen yang paling menyebabkan masalah ialah hepatitis B (HBV) dan Human Immunodeficiency Virus atau HIV. Hepatitis B adalah penyakit 
infeksi pada hati (hepar/liver) yang berpotensi fatal yang disebabkan oleh Virus Hepatitis B (VHB) dan merupakan salah satu penyakit yang sering ditemui dan menular. Penularannya sangat cepat, 100 kali lebih cepat dari HIV/AIDS dan dapat menyebabkan kematian.

Rumah sakit dalam kaca mata publik adalah unit service fungsional sebagai unit dalam service penyuluhan, mencegah serta perlakuan beberapa kasus segala jenis penyakit. Penyakit karena kerja bisa menyerang semua tenaga kerja di dalam rumah sakit, baik tenaga medis ataupun non medis karena pajanan biologi, kimia serta fisik di lingkungan kerja rumah sakit tersebut. Rumah sakit adalah tempat berkumpulnya beberapa orang sakit ataupun sehat, atau anggota penduduk baik petugas ataupun pengunjung, pasien yang mendapatkan perawatan di dalam rumah sakit dengan beberapa jenis penyakit menyebar. Perihal ini membuat rumah sakit adalah tempat kerja yang mempunyai kemungkinan pada masalah kesehatan serta kecelakaan kerja buat petugas. Beberapa jenis penyakit yang ada di lingkungan rumah sakit sangat mungkin rumah sakit jadi tempat penyebaran penyakit infeksi baik buat pasien, tenaga kerja ataupun pengunjung. Petugas di lingkungan rumah sakit begitu berdampak dengan kontak langsung pada agent penyakit menyebar lewat darah, sputum, jarum suntuk dan sebagainya.

\section{PENUTUP}

Kehidupan manusia tidak pernah terlepas dari pekerjaan, apapun jenis pekerjaan selalu dilakukan dalam rangka memenuhi kebutuhan sehari-hari, mulai dari pekerjaan berisiko rendah hingga berisiko tinggi.Pada hal faktor K3 sangat penting dan harus diperhatikan oleh pekerja dan hal ini menjadi tanggung jawab bersama.Tenaga kesehatan yang sering berkontak langsung dengan pasien adalah perawat. Kecelakaan kerja pada perawat dianggap sebagai suatu masalah serius karena mengancam kesehatan dan kesejahteraan pasien dan petugas kesehatan secara global (Maria, 2015). Kecelakaan tersebut yang pada akhirnya dapat mempengaruhi produktivitas kerja perawat. Produktivitas kerja yang rendah pada akhirnya berdampak terhadap pelayanan kesehatan yang diberikan oleh rumah sakit.

Pelaksanaan penerapan keselamatan dan kesehatan kerja di rumah sakit sangat penting untuk dilakukan semua SDM yang berada pada lingkungan masyarakat. Keselamatan dan kesehatan kerja hal utama yang harus kita wujudkan dilingkungan rumah sakit agar tidak terjadi insiden 
dan kecelakaan yang membahayakan dan merugikan pekerja, pasien, kelurga, pengunjung, dan masyarakat dilingkungan rumah sakit.

Risiko penyakit karena kerja bisa menyerang semua tenaga kerja di dalam rumah sakit, baik tenaga medis ataupun non medis karena pajanan biologi, kimia serta fisik di lingkungan kerja rumah sakit tersebut. Setiap pekerjaan tentu memiliki risiko masing-masing, tak terkecuali perawat. Meskipun lebih banyak bekerja di dalam ruangan dan tampak tak berbahaya, perawat justru berisiko tinggi untuk mengalami cedera. Tenaga profesi keperawatan harus mampu menjaga diri, untuk mengurangi tingkat risiko cedera akibat kerja pada perawat.

\section{DAFTAR PUSTAKA}

1. Azizah,N.,Setiawan.,\& Silaban,G. (2019). Hubungan antara pengawasan, prosedur kerja dan kondisi fisik dengan terjadinya kecelakaan kerja pada perawat di ruang rawat inap rumah sakitpermata bunda Medan tahun 2017. Jurnal JUMANTIK, 3(2).

2. Depkes RI. (2013). Pedoman pelaksanaan kewaspadaan universal di pelayanan kesehatan. Depkes RI. Jakarta.

3. Hanifa, N D., Titik R., \& Yuli S. (2017). Hubungan Pengetahuan dengan Upaya Penerapan K3 pada Perawat. 1(1).

4. Indragiri, S. (2018). Manajemen Risilo K3 Menggunakan Hazard Identification Risk Assessment Anda Risk Control (HIRARC). Jurnal Kesehatan, 9(1).

5. Mantiri, Ezra Zimri Ruben Abiam, Odi R. Pinontoan, dkk. (2020). FAKTOR PSIKOLOGI DAN PERILAKU DENGAN PENERAPAN MANAJEMEN KESELAMATAN DAN KESEHATAN KERJA RUMAH SAKIT. Indonesian Journal of Public Health and Community Medicine Vol. 1, No. 3.

6. Puspitasari, S. Supriyanto. Ginanjar, R. (2019). Faktor-Faktor yang Berhubungan dengan Kecelakaan Kerja Tertusuk Jarum Suntik atau Benda Tajam Lainnya Pada Perawat di RSUD Leuwiliang Kabupaten Bogor Tahun 2018. Promotor Jurnal Mahasiswa Kesehatan Masyarakat, 2(2)

7. Salawati, L. (2015). Penyakit Akibat Kerja dan Pencegahan. Jurnal Kedokteran Syiah Kuala 15(2). 
8. Silvia, Joko, dan Erlisa. (2015). Kejadian kecelakaan kerja perawat berdasarkan tindakan tidak aman. Jurnal Care, Vol. 3, No. 2

9. Simamora, R. H. (2017). A strengthening of role of health cadres in BTA-Positive Tuberculosis (TB) case invention through education with module development and video approaches in Medan Padang bulan Comunity Health Center, North Sumatera Indonesia. International Journal of Applied Engineering Research, 12(20), 10026-10035.

10. Simamora, R. H., \& Saragih, E. (2019). Penyuluhan kesehatan terhadap masyarakat: Perawatan penderita asam urat dengan media audiovisual. JPPM (Jurnal Pendidikan dan Pemberdayaan Masyarakat), 6(1), 24-31.

11. Tukatman, Sulistiawati, Purwaningsih, dan Nursalam. (2015). Analisis keselamatan dan kesehatan kerja perawat dalam penanganan pasien di rumah sakit benyamin guluh kabupaten Kolaka. Jurnal Ners, Vol. 10 No. 2

12. Umar, JE, Doda, VD \& Kekenusa, JS. (2017). Faktor-faktor Yang Berhubungan Dengan Kejadian Cedera Tertusuk Jarum Suntik Pada Perawat Di Rumah Sakit Liunkendage Tahunan. Jurnal Pascasarjana Ilmu Kesehatan Masyarakat, 2(4). 